\title{
DAMPAK PENURUNAN JUMLAH KUNJUNGAN KB TERHADAP ANCAMAN BABY BOOM DI ERA COVID-19 PMB BIDAN A KABUPATEN CIANJUR
}

\author{
Sri Hennyati $\mathbf{A}^{\mathbf{1})}$, Yeti Hernawati ${ }^{2)}$, Marien Wulan Anggriani ${ }^{3)}$ \\ ${ }^{\mathbf{1 , 2 , 3}}$ Program Studi Diploma Tiga Kebidanan Stikes Dharma Husada Bandung \\ 1) srihennyati@stikesdhb,ac,id \\ ${ }^{2}$ hernawati.yeti@gmail.com \\ ${ }^{3)}$ marienwulan1@gmail.com
}

\begin{abstract}
Abstrak
Seluruh dunia saat ini sedang terjadi sebuah pandemi yang mempunyai dampak cukup besar di semua sektor kehidupan manusia. World Health Organization (WHO) telah menetapkan Corona virus Disease 2019 atau COVID-19 sebagai sebuah ancaman pandemi, Pandemi COVID-19 memberikan implikasi ekonomi, sosial, politik dan kesehatan hampir di seluruh negara, termasuk di Indonesia. Kebijakan pemerintah untuk menerapkan social distancing, physcal distancing, work from home sebagai upaya pencegahan penularan covid-19, menyebabkan sulitnyaakses akpseptor KB terhadap layanan KB. Penurunan Kunjungan KB berisko meningkatnya jumlah kehamilan yang dapat diprediksi dengan bertambahnya jumlah kelahiran sekitar 4 juta bayi pada awal 2021 (Baby Boom). Penelitian ini bertujuan untuk mengetahui hubungan antara pengetahuan, status ekonomi, kesadaran dalam ber KB mandiri, persepsi pada tempat layanan terhadap variabel kunjungan KB. Metode penelitian ini adalah descriptive kuantitatif dengan pendekatan cross sectional. Pengambilan nya menggunakan pengumpulan data. Populasi dalam penelitian ini adalah 30 PUS yang berkunjung ke PMB Bidan A Kabupaten Cianjur. Tehnik pengambilan sampel menggunakan desain total sampling desaine, sampai terkumpul sampel penelitian 3030 responden selama pengambilan data. Analisis univariat dalam penelitian ini menggunakan sumber data sekunder yaitu rekam medis, literatur, artikel, dan jurnal. Hasil penelitian adalah ada hubungan antara pengetahuan terhadap kunjungan KB dan peningkatan penduduk.
\end{abstract}

\section{Kata Kunci : Kunjungan KB, Covid-19, Baby boom}

\section{PENDAHULUAN}

Dunia saat ini sedang terjadi sebuah pandemi yang mempunyai dampak cukup besar di semua sektor kehidupan manusia. World Health Organization (WHO) telah menetapkan Corona virus Disease 2019 atau COVID-19 sebagai sebuah ancaman pandemi. Pengertian pandemi menurut Kamus Besar Bahasa Indonesia (KBBI) merupakan wabah yang berjangkit serempak di mana-mana atau meliputi geografi yang luas. Kasus ini muncul bermula terjadi di Wuhan, Tiongkok dan mulai menyebar ke hampir seluruh dunia. Penyebaran COVID-19 ini sangat cepat dan tidak ada yang mempu memprediksi kapan berakhirnya pandemi COVID-19 ini.

Pandemi COVID-19 memberikan implikasi ekonomi, sosial, politik dan kesehatan hampir di seluruh negara, termasuk di Indonesia. The World Trade Organisation (WTO) memperkirakan bahwa volume perdagangan dunia secara global kemungkinan akan menurun sekitar 32\% pada tahun 2020 selama masa COVID-19. 
(Islam, 2020). Pembatasan aktivitas masyarakat sebagai upaya penanganan pandemi COVID-19 telah menimbulkan kerugian ekonomi yang signifikan secara nasional. Sektor yang terkena dampak selama pandemi COVID-19 adalah transportasi, pariwisata, perdagangan, dan pelayanan kesehatan.

Pelayanan kesehatan dan tenaga kesehatan bekerja ekstra demi memberikan penanganan pada pasien COVID-19 yang kini menjadi prioritas utama. Di sisi lain, adanya pandemi tidak menihilkan masalah maupun kebutuhan kesehatan lain yang perlu ditangani. Hal ini lah yang membuat fasilitas pelayanan kesehatan mulai selektif dalam memberikan pelayanan kesehatan. ${ }^{2}$

Pelayanan kesehatan menjadi perhatian bagi pemerintah, stakeholders, dan masyarakat, banyak langkah yang telah diambil demi mengatasi masalah ini terutama dengan mengeluarkan protokol dan regulasiregulasi yang bertujuan untuk memastikan bahwa pelayanan kesehatan berkualitas tetap tersedia dan dapat diakses oleh semua. Kebijakan ini beragam salah satu yang luput diperhatikan adalah soal pelayanan Keluarga berencana $(\mathrm{KB}){ }^{3}$

Pelayanan Keluarga Berencana (KB) dalam situasi Pandemi Covid-19 berdasarkan rekomendasi World Health Organization (WHO) dan masukan dari organisasi profesi dan lintas sektor terkait Badan Kependudukan dan Keluarga Berencana Nasional (BKKBN) maka disepakati rekomendasi untuk pelayanan
KB pada situasi pandemi yaitu Akseptor KB sebaiknya tidak datang ke petugas Kesehatan, kecuali yang mempunyai keluhan, dengan syarat membuat perjanjian terlebih dahulu dengan petugas Kesehatan, Bagi akseptor IUD/Implan yang sudah habis masa pakainya, jika tidak memungkinkan untuk datang ke petugas Kesehatan dapat menggunakan kondom yang dapat diperoleh dengan menghubungi petugas PLKB atau kader melalui telfon. Bagi akseptor Pil diharapkan dapat menghubungi petugas PLKB atau kader atau Petugas Kesehatan via telfon untuk mendapatkan Pil KB. Bagi akseptor Suntik diharapkan datang ke petugas kesehatan sesuai jadwal dengan membuat perjanjian sebelumnya dan dengan aturan prokes yang berlaku. $^{4}$

Tercatat bahwa jumlah peserta KB jenis akseptor suntik di Praktek Mandiri Bidan (PMB) di Bidan A Kabupaten Cianjur Jawa Barat periode maret 2019 hingga februari 2020 sebesar 857 akseptor. Capaian peserta KB mengalami penurunan secara signifikan selama pandemic pada bulan maret 2020 hingga februari 2021 sebanyak 695 akseptor. Dampak dari penurunan alat kontrasepsi atau akseptor KB salah satunya adalah terjadinya baby boom, kemungkinan jika pasangan suami istri melakukan hubungan seksualitas tidak menggunakan alat kontrasepsi adalah terjadi kehamilan, adapun alasan ibu - ibu tidak ber KB di masa pandemi dari hasil wawancara Wanita Usia Subur (WUS) sebanyak 10 orang, 3 karena masalah ekonomi, 4 mengatakan 
takut karena sedang pandemi, dan 3 mengatakan tetap ber KB di masa pandemi.

Penambahan jumlah kehamilan yang drastis dan bertambah pesat, selanjutnya Indonesia akan dihadapkan pada masalah Baby Boom atau ledakan jumlah bayi, untuk kelahiran sebelum pandemi dari bulan maret 2019 hingga februari 2020 tercatat sebanyak 105 kelahiran bayi, dan mengalami kenaikan yang cukup pesat pada bulan maret 2020 hingga februari 2021 di masa pandemi, menjadi sebanyak 133 kelahiran bayi. Permasalahan Baby Boom akan menambah permasalahan lain yang merupakan efek dari pandemi covid-19 selain permasalahan ekonomi, permasalahan gizi anak, dan kesehatan. Maka dari itu BKKBN mengeluarkan kebijakan untuk tetap menghimbau kepada akseptor KB untuk menunda kehamilan selama covid dengan tetap aktif mengikuti program KB. Selain itu kehamilan di masa pandemi covid-19 juga memiliki risiko terinfeksi lebih tinggi.

Untuk mencapai tumbuh kembang yang optimal dan mencegah kekurangan gizi, maka pemerintah melalui Kementrian Kesehatan menetapkan strategi pemberian makan bayi dan anak sesuai rekomendasi WHO dengan rekomendasi standar emas Pemberian Makan Bayi dan Anak (PMBA) yang meliputi Inisisasi Menyusu Dini (IMD), pemberian ASI eksklusif hingga usia 6 bulan, memberikan makanan pendamping ASI mulai usia 6 bulan dan melanjukan pemberian ASI sampai anak berusia 2 tahun. Dalam kondisi darurat seperti pandemi COVID-19 WHO merekomendasikan untuk tetap menyusui meskipun pada ibu yang terkonfirmasi positif COVID-19, selain itu upaya lain untuk meningkatkan status gizi bayi dan balita yaitu dengan pemberian Makanan pendamping (MP) ASI yang tepat dengan menu 4 bintang dengan bahan lokal. Masalah lain yang timbul adalah sindrom ASI berkurang sehingga ibu mengambil keputusan untuk memberikan minuman tambahan selain ASI. Pada masa pandemi COVID-19 membuat ibu menjadi khawatir dan bahkan menimbulkan stress yang mengakibatkan pengeluaan ASI terganggu. Pengeluaran ASI dipengaruhi hormon oksitosin dimana hormon ini sangat dipengaruhi oleh kondisi psikologi ibu. Oleh sebab itu pentingnya edukasi manajemen laktasi sehingga ibu tetap dapat menyusui secara optimal dalam kondisi apapun. ${ }^{5}$

Upaya dalam mencegah Baby Boom banyak menghadapi tantangan, pelayanan $\mathrm{KB}$ selama masa pandemi covid-19 adalah kurangnya pengetahuan pasangan usia subur (PUS) terkait Covid-19, tetapi banyak sekali informasi terkait covid-19 (WA/internet) yang belum tentu benar. Adanya fasilitas kesehatan baik primer/tempat Bidan Praktik Mandiri (PMB) maupun rujukan belum siap dalam pemenuhan Alat Perlindungan Diri (APD). Sarana prasarana pendukung protokol pencegahan covid-19 yang belum cukup. Adanya tenaga kesehatan yang belum tersosialisasi pedoman pelayanan $\mathrm{KB}$ di era pandemi Covid-19. Akses pelayanan KB 
selam covid-19 di fasilitas kesehatan primer/PMB juga terbatas karena pembatasan pelayanan. Meningkatnya kecemasan masyarakat karena banyak kasus orang tanpa gejala (OTG) yang beraktifitas seperti biasa, berisiko menularkan pada masyarakat, tapi kepatuhan masyarakat dalam protokol pencegahan covid-19 masih rendah. Dampak covid-19 terhadap ekonomi juga menyebabkan menurunnya day abeli terhadap alokon KB, terutama bagi PUS yang memilih pelayanan KB di klinik swasta atau PMB karena pertimbangan kontak dengan penderita covid-19 lebih rendah bila dibandingkan dengan pelayanan di RS pemerintah.

\section{METODE PENELITIAN}

Jenis penelitian yang digunakan adalah deskriftif, penelitian deskriftif merupakan penelitian yang didalamnya tidak ada analisis hubungan antar variabel, tidak ada variabel bebas dan terikat, bersifat umum yang membutuhkan jawaban di mana, kapan, berapa banyak, siapa dan analisis statistik.

Penelitian ini menggunakan teknik pendekatan waktu secara cross sectional dalam pengumpulan data. Cross-sectional study design adalah penelitian yang mendesain pengumpulan datanya dilakukan pada satu titik waktu (at one point in time) fenomena yang diteliti adalah selama satu periode pengumpulan data.

Jumlah sampel penelitian adalah 30 orang responden akseptor KB di PMB Bidan A Kabupaten Cianjur.
Sumber data adalah segala sesuatu yang dapat memberikan informasi mengenai data. Berdasarkan sumbernya, data dibedakan menjadi dua, yaitu data sekunder. Data skunder adalah data yang telah dikumpulkan untuk maksud selain menyelesaikan masalah yang sedang dihadapi. Data ini dapat ditemukan dengan cepat. Dalam penelitian ini yang menjadi sumber data sekunder adalah rekam medis, literatur, artikel, jurnal serta situs di internet yang berkenaan dengan penelitian yang dilakukan.

\section{HASIL DAN PEMBAHASAN}

\section{A. HASIL}

Hasil penelitian yang telah dilakukan kepada 30 responden mengenai "dampak penurunan jumlah kunjungan KB terhadap ancaman baby boom di era covid-19 PMB Bidan A Kabupaten Cianjur" dapat dilihat pada tabel sebagai berikut:

\section{Tabel 1 Distribusi Frekuensi penurunan jumlah kunjungan KB di era covid-19 PMB Bidan A Kabupaten Cianjur}

\begin{tabular}{llcc}
\hline No & Kategori & F & \% \\
\hline $\mathbf{1}$ & KB PIL & 9 & 30,0 \\
\hline $\mathbf{2}$ & KB Suntik & 10 & 33,3 \\
\hline $\mathbf{3}$ & KB IUD & 6 & 20,0 \\
\hline $\mathbf{4}$ & KB Implant & 5 & 16,7 \\
\hline & Total & 30 & 100,0 \\
\hline
\end{tabular}

Tabel 1 menunjukan terdapat penurunan jumlah kunjungan KB di era covid-19 PMB Bidan A Kabupaten Cianjur sebagian besar menggunakan KB Suntik, yaitu sebanyak 10 responden $(33,3 \%)$. 
a. Gambaran baby boom di era covid-19 PMB Bidan A Kabupaten Cianjur.

Tabel 2 Distribusi Frekuensi gambaran baby boom di era covid-19 PMB Bidan A Kabupaten Cianjur

\begin{tabular}{llcc}
\hline No & Kategori & F & \% \\
\hline $\mathbf{1}$ & Meningkat & 18 & 60,0 \\
\hline $\mathbf{2}$ & Tidak Meningkat & 12 & 40,0 \\
\hline & Total & $\mathbf{3 0}$ & $\mathbf{1 0 0 , 0}$ \\
\hline
\end{tabular}

Berdasarkan tabel 4.2 didapatkan hasil bahwa baby boom di era covid-19 PMB Bidan A Kabupaten Cianjur ada pada kriteria meningkat, yaitu dengan 18 responden $(60,0 \%)$.

b. Penurunan jumlah kunjungan KB terhadap ancaman baby boom di era covid-19 PMB Bidan A Kabupaten Cianjur

Tabel 3 Penurunan jumlah kunjungan KB terhadap baby boom di era covid19 PMB Bidan A Kabupaten Cianjur

\begin{tabular}{|c|c|c|c|c|c|c|}
\hline \multirow{3}{*}{$\begin{array}{l}\text { Penurunan } \\
\text { jumlah } \\
\text { kunjungan } \\
\text { KB }\end{array}$} & \multicolumn{4}{|c|}{$\begin{array}{l}\text { baby boom di era } \\
\text { covid-19 }\end{array}$} & \multirow{2}{*}{\multicolumn{2}{|c|}{ Total }} \\
\hline & \multicolumn{2}{|c|}{ Meningkat } & \multicolumn{2}{|c|}{$\begin{array}{c}\text { Tidak } \\
\text { Meningkat }\end{array}$} & & \\
\hline & $\mathrm{n}$ & $\%$ & $\mathrm{n}$ & $\%$ & $\mathrm{n}$ & $\%$ \\
\hline KB PIL & 5 & 27,8 & 4 & 33,3 & 9 & 30,0 \\
\hline KB Suntik & 7 & 38,9 & 3 & 25,0 & 10 & 33,3 \\
\hline KB PIL & 2 & 11,1 & 4 & 33,3 & 6 & 20,0 \\
\hline KB Implant & 4 & 22,2 & 1 & 8,1 & 5 & 16,7 \\
\hline Jumlah & 18 & 100 & 12 & 100 & 30 & 100 \\
\hline
\end{tabular}

Berdasarkan tabel 3 didapatkan hasil bahwa penurunan jumlah kunjungan $\mathrm{KB}$ suntik meningkat sebanyak 7 orang $(38,9 \%)$ dan yang mengalami penurunan jumlah kunjungan $\mathrm{KB}$ suntik tidak meningkat sebanyak 3 orang $(25,0 \%)$.

\section{B. PEMBAHASAN}

Penurunan jumlah kunjungan KB di era covid-19 PMB Bidan A kabupaten Cianjur. Berdasarkan hasil penelitian bahwa penurunan jumlah kunjungan $\mathrm{KB}$ di era covid-19 PMB Bidan A Kabupaten Cianjur sebagian besar menggunakan suntik sebanyak 10 responden $(33,3 \%)$.

Pemerintah Indonesia telah menetapkan bencana non alam penyebaran COVID-19 sebagai Bencana Nasional. Dalam menghadapi wabah bencana non alam COVID-19 ini dilakukan kebijakan Pembatasan Sosial Berskala Besar (PSBB) untuk pencegahan penularan COVID-19. Kondisi ini menyebabkan dampak terhadap kelangsungan pelayanan kesehatan masyarakat, termasuk pelayanan $\mathrm{KB}$ dan kesehatan reproduksi Kebijakan pemerintah untuk menerapkan social distancing, physcal distancing, work from home sebagai upaya pencegahan penularan covid-19, menyebabkan sulitnya akses akpseptor KB terhadap layanan KB.

Pelayanan KB di masa Covid-19 terhambat akibat keterbatasan persediaan alat KB dan seluruh sumber daya pelayanan kesehatan dikonsentrasikan untuk mendukung penanganan pandemi. Langkah-langkah lockdown yang diambil secara global untuk menanggapi COVID-19 membawa gangguan besar pada rantai pasokan kontrasepsi. Produsen kontrasepsi besar di Asia harus menghentikan produksi atau beroperasi pada kapasitas yang berkurang. Tenaga dan dana 
untuk layanan kesehatan seksual dan reproduksi di berbagai Negara dialihkan untuk penanganan COVID-19. Hal ini membuat perempuan dan anak perempuan tidak dapat mengakses kontrasepsi dan perawatan kesehatan seksual dan reproduksi lainnya.

Tindakan karantina dan pembatasan mobilitas (PSBB) akan mempengaruhi kemampuan perempuan dan anak perempuan untuk mencari layanan kontrasepsi. Ketidakamanan finansial dan beban pengasuhan tambahan yang disebabkan oleh tindakan lockdown akan menjadi hambatan lebih lanjut. Jika perempuan, anak perempuan dan komunitas yang terpinggirkan tidak dapat mengakses pelayanan kontrasepsi dalam krisis ini, maka akan terjadi peningkatan kehamilan yang tidak diinginkan dan paksa, peningkatan infeksi menular seksual, termasuk HIV, dan pada akhirnya, peningkatan tajam dalam aborsi yang tidak aman. Dampaknya pada kehidupan perempuan dan anak perempuan sekarang, dan setelah krisis ini, akan sangat parah.

Berdasarkan penelitian yang dilakukan oleh (Aly et al., 2020). ${ }^{15}$ bahwa akses ke fasilitas pelayanan kesehatan sangat terbatas dan masyarakat mulai menghindari ke fasilitas kesehatan karena kekhawatiran tertular COVID-19. Satu dari tiga wanita (33\%) melaporkan bahwa karena pandemi, harus menunda atau membatalkan kunjungan ke penyedia layanan kesehatan (Lindberg et al., 2020).

Menurut penelitian (Witono \& Suparna, 2020) menyebutkan bahwa Kondisi ini juga terjadi DIY bahwa sejak pandemi Covid-19 jumlah peserta KB aktif mengalami penurunan. Penurunan peserta KB aktif bulan Maret - April 2020 pada kontrasepsi nonMKJP jenis kontrasepsi suntik dan pil yang menurun sebesar 0,5 dan 0,4 persen. Jumlah peserta KB baru juga menunjukkan penurunan pada bulan Maret dan April 2020 dan terdapat kecenderungan penurunan jumlah peserta $\mathrm{KB}$ baru di seluruh kabupaten/kota. Peserta KB baru di DIY lebih banyak yang memakai kontrasepsi non-MKJP (58,91 persen pada April 2020). Sementara unmet need KB cenderung terus mengalami kenaikan, dari 10,2 persen pada bulan Januari 2020 menjadi sekitar 10,36 persen pada bulan April 2020. Jumlah peserta KB baru tampak mengalami penurunan pada bulan Maret-April 2020 seiring dengan penambahan jumlah kasus positif Covid-19 di DIY.

1. Gambaran ancaman baby boom di era covid-19 PMB Bidan A Kabupaten Cianjur Berdasarkan hasil penelitian bahwa baby boom di era covid-19 PMB Bidan A Kabupaten Cianjur ada pada kriteria meningkat, yaitu dengan 18 responden $(60,0 \%)$.

Ancaman terjadinya baby boom pasca wabah covid-19 sudah mulai meresahkan pemerintah. Bertambahnya jumlah penduduk akan menambah deretan PR pemerintah yang harus segera diatasi. Mengingat kondisi Indonesia yang masih berbenah dan bangkit pasca covid19.

Agar ancaman adanya baby boom tidak terjadi maka perlu adanya tindakan khusus dalam 
tubuh BKKBN. Persiapan untuk berkoordiansi dengan pemerintah, pengadaan sosialisasisosialisasi tentang $\mathrm{KB}$, memberikan fasilitas jemput pasien kerumah rumah dan menurunkan kader-kader KB untuk membantu masyarakat yang membutuhkan pelayan $\mathrm{KB}$ secara fleksibel.

BKKBN memperkirakan peningkatan angka kehamilan tidak terencana selama masa pandemi Covid-19 mencapai 420 ribu. Hasil survei yang dilakukan DKT Indonesia bersama lembaga riset independen untuk mengukur pengaruh pandemi terhadap pola konsumsi kontrasepsi, khususnya metode Suntik KB dan Pil KB bahwa (1) Sebanyak 26\% bidan menyampaikan pandemi Covid-19 berdampak pada pemasukan klinik mereka, sedangkan $56 \%$ bidan menyatakan pandemi tidak berdampak terhadap kegiatan praktik kliniknya. (2) Jumlah layanan suntik KB di mayoritas Praktik Mandiri Bidan (PMB) tidak mengalami perubahan. Pada sebagian kecil responden yang mengalami penurunan layanan suntikan mengatakan hal tersebut dipengaruhi oleh menurunnya daya beli konsumen, dan karena akseptor mereka takut untuk datang ke klinik. (3) Pola permintaan terhadap layanan suntik KB mengalami penurunan pada masa penetapan PSBB, namun sudah mulai meningkat pada satu hingga dua bulan terakhir. Secara umum tidak terjadi perubahan pola rekomendasi metode secara drastis. (4) Responden merasa pandemi memberikan keuntungan bagi bisnis apotek, terutama pada segmen produk untuk peningkatan vitalitas dan daya tahan tubuh. Sedangkan $34 \%$ responden menyatakan terjadi penurunan penjualan pada masa PSBB. (5) Sebanyak 40\% responden mengaku kontrasepsi menjadi salah satu item yang paling banyak dicari di apotek pada masa pandemi. (6) Adanya peningkatan frekuensi aktivitas seksual, khususnya pada kelompok usia pasangan yang lebih muda. (7) Perlu diantisipasi adanya penurunan kepesertaan $\mathrm{KB}$ akibat menurunnya daya beli masyarakat, serta pola distribusi dan pelayanan yang dapat mengurangi risiko penularan Covid-19, baik bagi akseptor, maupun bagi penyedia layanan (termasuk petugas apotek).

Pada kondisi pandemi ini diharapkan kepada pasangan usia subur (PUS ) terutama PUS dengan 4 Terlalu (4T) diharapkan untuk menunda kehamilannya terlebih dahulu dan petugas kesehatan tetap memantau mereka dalam penggunaan kontrasepsi. dalam menghadapi pandemi covid 19 ini, pelayanan kebidanan terutama pelayanan kesehatan reproduksi perempuan tetap dilakukan tentunya dengan menerapkan prinsip pencegahan pengendalian infeksi dan physical distancing. Panduan pelayanan keluarga berencana menyebutkan bahwa pesan yang harus disampaikan kepada masyarakat yaitu (1) Tunda kehamilan sampai kondisi pandemi berakhir, (2) Akseptor KB sebaiknya tidak datang ke petugas Kesehatan, kecuali yang mempunyai keluhan, dengan syarat membuat perjanjian terlebih dahulu dengan petugas Kesehatan, (3) Bagi akseptor IUD/Implan yang sudah habis masa pakainya, jika tidak 
memungkinkan untuk datang ke petugas

Kesehatan dapat menggunakan kondom yang dapat diperoleh dengan menghubungi petugas PLKB atau kader melalui telfon. Apabila tidak tersedia bisa menggunakan cara tradisional (pantang berkala atau senggama terputus), (4) Bagi akseptor Suntik diharapkan datang ke petugas kesehatan sesuai jadwal dengan membuat perjanjian sebelumnya. Jika tidak memungkinkan, dapat menggunakan kondom yang dapat diperoleh dengan menghubungi petugas PLKB atau kader melalui telfon. Apabila tidak tersedia bisa menggunakan cara tradisional (pantang berkala atau senggama terputus), (5) Bagi akseptor Pil diharapkan dapat menghubungi petugas PLKB atau kader atau Petugas Kesehatan via telfon untuk mendapatkan Pil KB, (6) Ibu yang sudah melahirkan sebaiknya langsung menggunakan KB Pasca Persalinan (KBPP), (7) Materi Komunikasi, Informasi, dan Edukasi (KIE) serta pelaksanaan konseling terkait $\mathrm{KB}$ dapat diperoleh secara online atau konsultasi via telpon.

Potret yang terjadi tahun 50-60 merupakan lampu merah bagi pemerintah, untuk menghindari permasalahan yang akan lebih kompleks, Dengan bertambahnya penduduk Indonesia maka akan timbul masalah baru pada tingkat kesejahtreraan rakyat se Indonesia. harapan untuk menekan nilai kemiskinan menjadi mimpi disiang bolong.

Wabah Covid-19 benar-benar telah memporak porandakan ekonomi khusunya rakyat Indonesia. Banyaknya pengangguran, bertambahnya jumlah kelahiran. Akan meninggalkan catatan pilu sejarah di tahun 2020-2021.

\section{KESIMPULAN}

1. Gambaran penurunan jumlah kunjungan $\mathrm{KB}$ di era covid-19 PMB Bidan A Kabupaten Cianjur sebagian besar menggunakan KB Suntik, yaitu sebanyak 10 responden $(33,3 \%)$.

2. Gambaran baby boom di era covid-19 PMB Bidan A Kabupaten Cianjur ada pada kriteria meningkat dengan persentase $(60,0 \%)$.

\section{DAFTAR PUSTAKA}

Handayani, R. T., Arradini, D., Darmayanti, A. T., Widiyanto, A. \& Atmojo, J. T. Pandemi covid-19, respon imun tubuh, dan herd immunity. J. Ilm. Stikes Kendal 10, 373-380 (2020)

BKKBN, (2020) Antisipasi Baby Boom Pasca Pandemi Covid-19, BKKBN jalankan pelayanan $\mathrm{Kb}$ dengan Tetap Menjaga jarak dan konseling Melalui Media Online, Siaran Pers No. Rillis/54/BKKBN/V/2020 2 Mei 2020 https://www.bkkbn.go.id/detailp ost/antisipasi-baby-boom-pascapandemi-covid-19-bkkbn- jalankanpelayanan-kb-dengan- tetap-menjagajarak-dan- konseling-melalui-mediaonlineAkses Juni 2020

BKKBN, (2020) Hasil Pelayanan Peserta KB Baru yang dilayani oleh Fasilitas Kesehatan Pemerintah dan Swasta peride Januari-Mei 2020, https://www.bkkbn.go.id/, Akses Juni 2020

\section{Satuan Tugas Penanganan COVID-19 https://covid19.go.id/ Akses Juni 2020}


Health Avenir, (2020), Impact of the COVID-19 Pandemic on Family Planing and Ending Gender Based Violence, Female GenitalMutilation and child Marriage, UNFPA https://www.unfpa.org/resource s/impact-covid-19-pandemicfamily-planning-and-endinggender-based-violence-femalegenital Akses Juni 2020

Manuaba, Ida Ayu Chandra, (2009), Memahami Kesehatan Reproduksi Wanita, Jakarta, EGC

Keputusan Kepala BKKBN No 108/KEP/BI/2020 tentangPenetapan Indikator Kinerja Utama (IKU) BKKBN tahun2020-2024

Kenneth J, Leveno et al, (2003) Wiliams Manual Of Obstetrics, 21"ed, Jakarta:EGC

Mamelund, S.E (2004), Can the Spanish Influenza Pandemic of 1918 Explin the Baby Boom of 1920 in Neutral Norway.Population-E, 59 (2), 229-260

Laura D. Lindberg, Alicia VandeVusse, Jenifer Mueller

and Marielle Kirstein, all (2020),Early Impacts of the Covid-19 Pandemic : Finding from the 2020 Guttmacher Survey of Reprdouktive Health Experiences, New York: Guttmacher Institute, 2020.

Notoatmodjo,S.(2005).Metodologi penelitian kesehatan.Jakarta:Rineka Cipta.

Pratiknya, Watik. (2003). Dasar-dasar metodologi penelitian kedokteran dan kesehatan. Jakarta: PT

RajaGrafindoPersada

Santjaka, Aris. (2011). Statistik untuk penelitian kesehatan. Yogyakarta: Nuha Medika.

Saputra, D (2020) Fenomena Informasi Palsu (Hoax) padaMedia Sosial di Tengah.

Rosidin, U. Rahayuwati, L. Erna, H. (2020) Perilaku dan Peran Tokoh Masyarakat dalam Pencegahan dan Penanggulangan pandemi Covid-19 di Desa Jayaraga, Kabupaten Garut. Indonesian Journal of Anthropologi, Vol. 5. No 1. 2020

Saputra, D (2020) Fenomena Informasi Palsu (Hoax) padaMedia Sosial di Tengah

Pandemi Covid-19 dalam Perspektif Islam, Journal Dakwah dan Ilmu Komunikasi. Vol. 2, No. I, JanuariJuni (2020) P-ISSN: 2685-5305, E-ISSN: 2686-3790 Purwanti, S.

Dampak Penurunan Jumlah Kunjungan Kb Terhadap Ancaman Baby Boom Di Era Covid-19. J. Bina Cipta Husada XVI, 105-118 (2020).

UNFPA, (2020) Coronavirus Disease (COVID-19) Pandemic global Response Plan, UNFPA https://www.unfpa.org/resource s/coronavirus-disease-covid-19pandemic-unfpa-global- response-plan akses juni 2020 